\title{
Localization of the human dihydrolipoamide dehydrogenase gene (DLD) to $7 \mathrm{q} 31 \rightarrow \mathrm{q} 32$
}

\author{
S.W. Scherer, ${ }^{1,4}$ G. Otulakowski, ${ }^{3}$ B.H. Robinson, ${ }^{2-4}$ and L.-C. Tsui ${ }^{1,4}$ \\ Departments of 1 Medical Genetics, ${ }^{2}$ Biochemistry, and ${ }^{3}$ Pediatrics, University of Toronto, and \\ ${ }^{4}$ Department of Genetics, Research Institute, The Hospital for Sick Children, Toronto, Ont. (Canada)
}

\begin{abstract}
The gene for human dihydrollipoamide dehydrogenase (DLD) has been localized to the long arm of chromosome 7 , within bands $\mathrm{q} 31 \rightarrow \mathrm{q} 32$, by gel-blot hybridization analysis
\end{abstract}

with DNA from a panel of somatic cell hybrids contaning rat ious portions of human chromosome 7 .
Dihydrolipoamide dehydrogenase (commonly known as lipoamide dehydrogenase, or DLD [E.C.1.8.1.4.]) is a $50-\mathrm{kDa}$ subunit protein comprised of at least three distinct mitochondrial multienzyme complexes: the pyruvate dehydrogenase complex, the 2-oxoglutarate dehydrogenase complex, and the branched chain $\alpha$-keto and dehydrogenase complex (Sakurai et all, 1970). Functionally, this enzyme acts to transfer a pair of electrons from reduced lipoyl groups to NAD within each of these complexes, thus releasing oxidized lipoate to participate in reductive acylation. It may also participate in another multienzyme complex that is responsible for glycine cleavage (Kochi et al., 1986; Carothers et al., 1987). A rare inborn error of metabolism in man characterized by reduced lipoamide dehydrogenase activity and concomitant reduction of all $\alpha$-keto acid dehydrogenase complex activities has been described in a small number of patients (Robinson, 1989). Isolation and sequencing have been reported for cDNAs encoding the entire protein sequence of human (Otulakowski and Robinson, 1987; Pons et al., 1988) and porcine (Otulakowski and Robinson, 1987) lipoamide dehydrogenase and the human gene assigned to chromosome 7 (Otulakowski et al., 1988; Olson et al., 1990).

Using a panel of rodent $\times$ human somatic cell hybrids containing various portions of chromosome 7 , we have refined the chromosome localization of the human DLD gene to $7 \mathrm{q} 31 \rightarrow \mathrm{q} 32$.

\footnotetext{
Supported by grants from the Medical Research Council of Canada (MRC). L.-C.T. is an MRC Scientist and Selllers Chair of Cystic Fibrosis Research.

Received 29 August $\| 990$; accepted 29 Octaber $\| 990$.

Request reprints from Dr. Lap-Chee Tsui, Department of Genetics, The Hospital for Sick Children, 555 Uniwersity Avenue, Toronto, Ont. M5G IX8 (Canada).
}

The somatic cell hybrids used in the hybridization analysis hare ho described previously (Zengerling et al., 1987; Rommens et al, 1989.7 17 amount of human chromosome 7 present in each of these hybrids is shon Fig. 1. High-molecular-weight DNA $(5-10 \mu \mathrm{g})$ was isolated from fyobih at lines, digested with EcoRI, separated by electrophoresis on a $0.8 \%$ ogeng gel, and transferred to nyllon membranes (Zetia-probe, Bio-Radi, A thy fragment from the cDNA clone LD4a (Otulakowski and Robiuson, 13 th labeled with $[a-32 \mathbb{P}] \mathrm{dCTP}$ by the random priming method (Feintong un Vogelstein, 1983), was used as the probe in the hybridization analysis. Fint were prehybridized and hybridized in CGH solution $(0.5 \mathrm{~N}$ sodium phis phate buffer [pH 7.2], $1 \mathrm{mM}$ EDTA, $7 \%$ SDS) at $65^{\circ} \mathrm{C}$ (Church and Giltet 1984). Following hybridization, the blots were washed three times consur

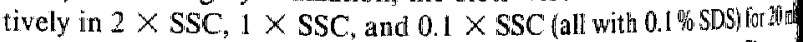
each at $65^{\circ} \mathrm{C}(\mathrm{SSC}=150 \mathrm{mM} \mathrm{NaCl}, 15 \mathrm{mM}$ sodium citrate $)$. The filers is at exposed to Kodak XAR-5 film with intensifying screens for $\mathrm{L}-6 \mathrm{~d}$ drin $-70^{\circ} \mathrm{C}$.

An example of the hybidization results is shown in $\mathrm{Fiz}$ ? and the data are summarized in Fig. 1. As shown in Fige 2. ds DLD cDNA probe detected a single $4.0-\mathrm{kb}$ band in all of th hybrids containing human DNA from the $7 q 31 \rightarrow q, 32$ a $x$ ind but not in hybrids that did not contain this region. The 4. human-specific band was easily distinguished from crosshy bridizing sequences (presumably the corresponding geresest the mouse and hamster DNAs. The regional localization idd mation for DLD was derived mainly from the hybridizaline resullt with the human $\times$ mouse hybrid GM1059Rag5, whil contained a single human chromosome 7 with an intersilith

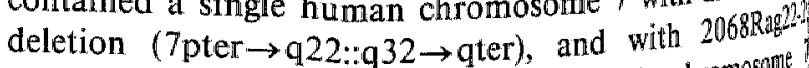
which contained a single translocated chromosome (7qter $\rightarrow$ q22:) (Rommens et al., 1988). The result drexth showed that the DLD sequence was present in 2068Rag 22:2th absent in GM1059Rag5, indicating that the DLD gene tith within $7 \mathrm{q} 31 \rightarrow \mathrm{q} 32$. 
7

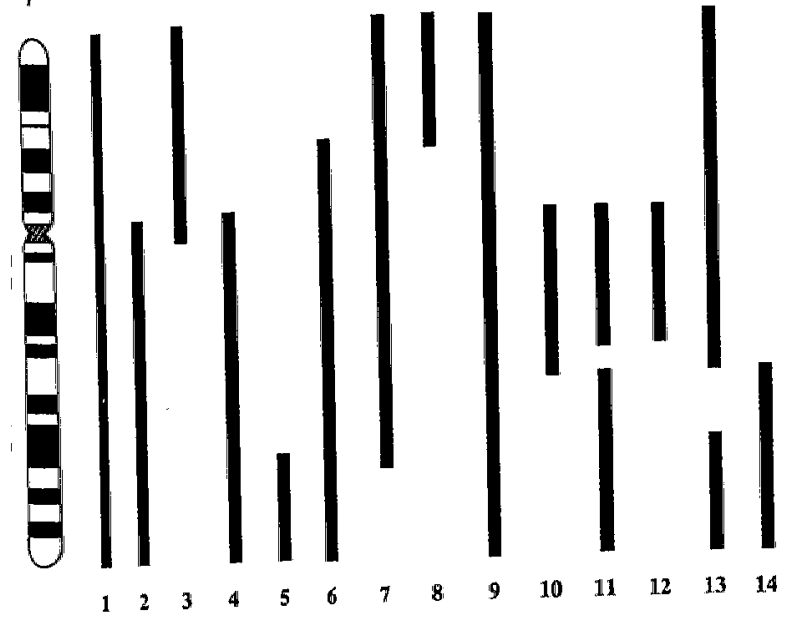

LDaㅡ

Fig. 1. Somatic cell hybrid lines and summary of hybridization data. The 10 panell shows the human $X$ todent somatic cell hybrid lines used in this hady and the portion of human chromosome 7 contained in each of them. be presence (+) or absence (-) of the DLD gene in each of these cell lines was etermined by gel-blot hybridization analysis with the cDNA probe. Examths of uthe hybridization results are presented in Fig. 2, but not all the results reshown.

A detailed long-range restriction map has been constructed lor $4.5 \times 10^{6}$ bp region encompassing the gene for cystic fibroNis(CF) (Drumm et al., 1988; Poustka et al., 1988; Rommens et 14, 1989). Preliminary data (not shown) suggest that DLD is not hincllose proximity of the met protooncogene (MET), CF, and D7S8, which, together, span approximately $1.5 \times 10^{6} \mathrm{bp}$. Over (0 unique chromosome 7 -specific DNA fragments have been bealized to the $7 \mathrm{q} 31 \rightarrow \mathrm{q} 32$ interval with use of the somatic cell

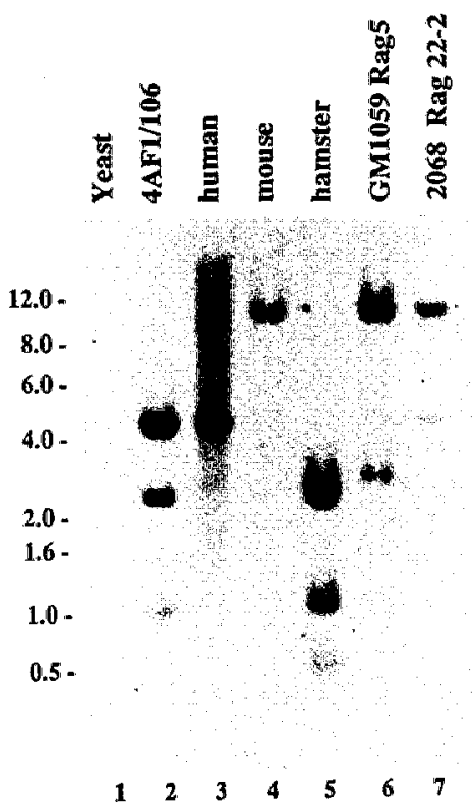

Fig. 2. Examples of gel-blot hybridization. The autoradiograph shows the esult of bybridization of the LD4a cDNA to two of the somatic cell hybrids, result of hybridization of the 22-2. Total humanu, mouse, and hamster DNAs

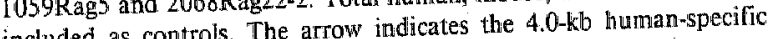
sequence present in lanes 2,3, and 7 .

hybrids described here (Rommens et al., 1988). The localization of the DLD gene to this interval, which is estimated to be approximately $30 \times 10^{6}$ bp in size, adds yet another DNA segment for use in the construction of a long-range physical map of $7 \mathrm{q} 31 \rightarrow \mathrm{q} 32$, now underway.

The authors wish to thank. Prof. Karl-Hleinz Grzeschik for providing most of the somatic hybrid cell lines for this study.
Cocmolluers DI, Raefsky-Estrin C, Pons G, Patell MS: Rat linser mitochondria contain two immunologically distinet dilhydrolipoamidle dehydrogenases. Arehs Bineshen Biophys 256:597-605 (1987).

Thurch GM, Gilbert W: Genomic sequencing. Proc natl Acad Sci, USA 81:1991-1995 (19844).

Drumm ML, Smith CL, Dean M, Cole JL, Iannuzzi M, Collins FS: Physical mapping of the cystic fibrosis region by pulsed-field gel electrophoresis. Genonines 2:346-354 (1988)

Feinbirirg AP, Yogelstein B: A technique for radiolabeling DNA restriction endonuclease fragments to lijigh specific activity. Analyt Biochem 132:6-13 (1983)

Kochin H, Seino H, Ono $\mathbb{K}$ : Inhibition of glycine oxidathion by pyruvate, a-ketoglutarate and branched: chiain a-keto acids in rat liver mitochondria: interaction between the glycine cleavage system and the a-keto acid dehydrogenase complexes. Archs BioOlkon S Biophys 249:263-272 (1986)

Wor Song BJ , Huh T-L, Chi Y-T, Veach RL MeBride OW: Three genes for enzymes of the pyruvate delhydrogenase complex map to human chro- mosomes 3, 7 and X. A.m J hum Genet 46:340-349 (1990).

Rolinson BH: Isolation and sequence lakowski $G$, Robinson BH. Isolation and ane and hudetermination of $C D N A$ clogenase. $J$ biol Chem man lipoamide deliydrogent

列 lipons to human chromolipoarnide dehydrogenase maps to hul1-414(1988) some 7. Sornat Cell molec Gienet 14:411-414(1).

Pons G, Raefsky-Estrin C, Carothers D, Pepin R, Javid AA, Jesse BW, Gamapathi MK, Samols D, Patel MS: Cloning and $c D N A$ sequence of the dihydrolipoamide delyydrogenase component of human aketoacid dehydrogenase comples (1988).

Sci, USA 85:1422-1426(1988). Bates G: A long-

Poustka A, Lebrach $\mathrm{H}$, Williamson R, Bates $\mathrm{G}$. A, long range restriction map cncompassing the cysarkers. brosis locus and its closely lin Genomics. 2:337-345 (1988).

Terrer Beaudet abinson BH: Lactic acidemia, in Scriver CR, Beand AL, Sly WS, Valle D (eds): The Metabolic Basis ow YorkToronto 1989).
Rommens.JM, Zengerling S, Burns J, Meelner G, Kerem B, Plasvic N, Zsiga M, Kennedy D, Markiewicz D, $B$, Plasvic N, Zsiga M, JR, Buchwald M, Tsui L-C: Rozmaliel R, Riordan JR, Bul localization of DNA Identification and regional localization of DNA Identiries on chromosome 7 for the cloning of the markers on chromosome 7 hum Gemet 43:645-663 cystic fic
(1988).

(1988). Rommens JM, Zengerling-Lentes Sysical focalization of $G$, Buchwalid $M$, Tsui L-C: Physical hocalizanstic fibrotwo DNA markers closely linked to the cystic fibrosis locius by pulsed-field gel electo hum Genet 45:9.32-9.41 (1989). Sakurai Y, Fukuyoshi Y, Hameda M, Ha datrogeKoike M: Multiple forms of lipoamide denase commase in pig heart a-keto acid delyydrogenase nase in pig hem 245:4453-4458 (1970). plexes. J biol Chem 245.4453 - Greschik K-H, Rior-

Zengerling S, Olek K, Tsui L-C, Grzesch DNA markers dan JR, Buchwald Mf: Mapping of DNA markers linked to the cystic fibrosis locus an the long arm of chromosome 7. Am J hum Genet 40:228-236 (1987) 